\title{
Copper sulphate induced changes in scaphognathite oscillations and oxygen consumption of fresh water prawn, Macrobrachium lamarrei (Crustacea- Decapoda)
}

Dharm Raj Verma, Harnam Singh Lodhi, Kunwer Ji Tiwari, Sanjive Shukla* and U.D. Sharma**

P.G. Department of Zoology, B S N V P G College, Lucknow - 226001 (U.P.), INDIA

**Prawn Research Centre, Department of Zoology, University of Lucknow, Lucknow-226 007 (U.P.), INDIA

*Corresponding author. E-mail: sanjiveshukla@gmail.com

Abstract: Fresh water prawns, Macrobrachium lamarrei were subjected to acute concentration, $0.304 \mathrm{mg} / \mathrm{l}$ ( $96 \mathrm{~h}$ $\mathrm{LC}_{50}$ ) of Copper sulphate to evaluate its effects on scaphognathite oscillations and oxygen consumption rate. Scaphognathite oscillations showed initial increase after $24 \mathrm{~h}$, thereafter significantly $(t=9.24 ; P<0.001)$ decreased up to $72 \mathrm{~h}$ and finally tend to increase after $96 \mathrm{~h}$ but remained below the controls where as oxygen consumption showed continuous decreasing trend through out the experiment up to $96 \mathrm{~h}(\mathrm{t}=16.53 ; \mathrm{P}<0.001)$ than control ones. Possible interaction of copper in relation to respiration of these economically important crustaceans has been discussed.

Keywords: Macrobrachium lamarrei, Scaphognathite oscillations, Oxygen consumption, Copper sulphate

\section{INTRODUCTION}

Heavy metal pollution is one of the serious problems of fresh water bodies which are highly vulnerable to natural and anthropogenic interferences than comparatively stable marine ecosystem (Sanders, 1997). Due to some properties like high solubility, long half life period, non bio-degradable nature and tendency of bioaccumulation and bio-magnification they cause deleterious effects on aquatic flora and fauna as well as directly or indirectly affect human health (Chopra et al., 2009).

Among heavy metals, Copper is a reddish metal that occurs naturally in rocks, soil, water, sediment and air ; enters in environment by various natural and industrial processes. It is an essential element for all known organisms including humans and other vertebrates for normal biological functions of many proteins and enzymes necessary for growth and development (Liu et al., 1990 and Mandez et al., 2001). Copper is also used to eradicate filamentous algae as well as to reduce phytoplankton in aquaculture ponds and become highly toxic to aquatic organisms when present in higher concentrations (Sorensen, 1991; and Chen and Lin, 2001). Toxic effect of copper and other heavy metals are mostly investigated in fishes (Tasi,1979; RamanRao and Ramamurthi, 1987; Gill et al., 1988; Varghese et al., 1992; Pane et al., 2003; Drastichova et al., 2004; Sindal et al., 2004; Prashanath et al., 2005 and Svecevièus, 2005) but crustaceans despite having high economic and medicinal value are less documented (Chinnayya, 1971; Lodhi et al., 2006; Sharma and Shukla, 2006; Li-Na, et al.2007 ; Yang et al.2007; ISSN : 0974-9411 All Rights Reserved $\odot$ Applied and Natural Science Foundation www.ansfoundation.org
Jadhav and Ambrose, 2007; and Lodhi ,2009).

The present work was undertaken to evaluate the effects of copper sulphate on scaphognathite oscillations and oxygen consumption of fresh water prawn, Macrobrachium lamarrei (Crustacea - Decapoda), a potential animal for freshwater aquaculture.

\section{MATERIALS AND METHODS}

Fresh water prawns, Macrobrachium lamarrei (H. Milne Edward) were collected from river Gomti, Lucknow (U. P.) - India, with the help of local fisherman and brought to the laboratory $\left(\mathrm{N}-26^{\circ} 49^{\prime} 55^{\prime}\right.$ ' E- $\left.80^{\circ} 55^{\prime} 58^{\prime \prime}\right)$ in large plastic containers. The animals were maintained in glass aquaria of 20 liter capacity, in dechlorinated water having physico-chemical characteristics as follows: $\mathrm{pH}-7.6 \pm$ 0.2, Temperature - $26.0 \pm 2.0{ }^{\circ} \mathrm{C}$, D.O. - $7.0 \pm 0.1 \mathrm{mg} / \mathrm{l}$, Hardness - $298 \pm 2.5 \mathrm{mg} / \mathrm{L}$, Alkalinity $-65 \pm 4.5 \mathrm{mg} / \mathrm{l}$ (APHA, 1998). Stock solution of Copper sulphate [CuSO4.5H2O, AR Grade molecular weight $249.68 \mathrm{gm} / \mathrm{mole}$, manufactured by - Qualikems fine chemicals Pvt. Ltd., New Delhi, 110060 India] was prepared by dissolving weighed amount of salt in double distilled water. Two drops of Glacial acetic acid was added to prevent the precipitation.

Adult inter-moult staged $M$. lamarrei (Average length $4.86 \pm 0.55 \mathrm{~cm}$, weight $-1.107 \pm 0.26 \mathrm{gm}$.) were being utilized in experiments after 5-7 days acclimation to laboratory conditions. Acute exposure was carried out on predetermined $96 \mathrm{~h} \mathrm{LC}_{50}$ values $(0.304 \mathrm{mg} / \mathrm{lit}$; $95 \%$ confidence limits: lower $-0.304 \mathrm{mg} / \mathrm{lit}$; upper $0.380 \mathrm{mg} / \mathrm{lit}$; Lodhi et al., 2006). One aquarium containing diluent water 
only served as control for each set. Feeding was suspended $24 \mathrm{~h}$ before during acute exposure and through out experiment. Continuous air supply was provided with the help of air diffusers and aerators in both control as well as experimental aquaria. Experiment was carried out according to guidelines of APHA (1998) and scaphognathite oscillations were recorded under stereoscopic dissecting binocular microscope with the help of stop watch from both control and experimental animals. The respiratory rate was determined by hourly monitoring of dissolve oxygen contents according to Winkler's method (APHA, 1998). The oxygen consumption rate was calculated as oxygen consumed $(\mathrm{mg} / \mathrm{l} / \mathrm{gm}$ body weight/h. Experiment was replicated thrice and data were subjected to statistical analysis for student" t" test and "ANOVA" using MINITAB software on PC.

\section{RESULTS}

Copper sulphate induced marked alterations in scaphognathite oscillations and oxygen consumption of freshwater prawn, $M$. lamarrei and data are summarized in Table 1 and Table 2. Scaphognathite oscillations were found increased $(253.8 \pm 4.59)$ than the controls $(247.7 \pm$ $2.85)$ after $24 \mathrm{~h}$ of exposure. Thereafter a decline was noticed after $48 \mathrm{~h}(227 \pm 4.34)$ and $72 \mathrm{~h}$ exposure $(210 \pm 1.97)$ than the controls $(248.7 \pm 3.33$ and $245.6 \pm 3.26)$. Scaphognathite oscillations further tend to increase up to $96 \mathrm{~h}(231.1 \pm 2.42)$ but remained below the controls $(246.1$ \pm 4.30 ). The difference between means of control and the test animals were moderately significant $(\mathrm{t}=3.04 ; \mathrm{P}<0.01)$ after $96 \mathrm{~h}$; significant $(\mathrm{t}=3.96 ; \mathrm{P}<0.05)$ after $48 \mathrm{~h}$ and highly significant $(\mathrm{t}=9.24 ; \mathrm{P}<0.001)$ after $72 \mathrm{~h}$ while were nonsignificant $(\mathrm{t}=1.13 ; \mathrm{P}>0.01)$ after $24 \mathrm{~h}$ exposure. The overall fluctuations in scaphognathite oscillations were non-significant $(\mathrm{f}=0.17 ; \mathrm{P}>0.5)$ in controls while significant $(\mathrm{f}=25.73 ; \mathrm{P}<0.001)$ in experimental animals. Experimental prawns showed continuous declining trend in oxygen consumption $(0.4152 \pm 0.008,0.3677 \pm 0.0012$, $0.3189 \pm 0.0089,0.2825 \pm 0.0062 \mathrm{mg} / \mathrm{l} / \mathrm{gm}$. body weight $/ \mathrm{h}$ ) through out the experiment ( $24,48,72$ and $96 \mathrm{~h}$ exposure) than control ones. The differences between means of the control and experimental animals were non-significant $(\mathrm{t}=2.71 ; \mathrm{P}>0.05)$ after $24 \mathrm{~h}$ while moderately significant $(\mathrm{t}$ $=3.86 ; \mathrm{P}<0.05 ; \mathrm{t}=10.14 ; \mathrm{P}<0.01)$ after 48 and $72 \mathrm{~h}$ respectively and highly significant $(t=16.53 ; \mathrm{P}<0.001)$ after $96 \mathrm{~h}$ exposure. The overall fluctuations in oxygen consumption of controls were non-significant $(\mathrm{f}=4.41$; $\mathrm{P}>0.01)$ while highly significant $(\mathrm{f}=44.74 ; \mathrm{P}<0.001)$ in experimental group.

\section{DISCUSSION}

Present study revealed that Copper caused marked alterations in scaphognathite oscillations and continuous decrease in oxygen consumption in freshwater prawn,
Table 1. Effect of Copper sulphate on Scaphognathite oscillations in Macrobrachium lamarrei.

\begin{tabular}{ccc}
\hline $\begin{array}{c}\text { Duration of } \\
\text { Exposure }\end{array}$ & \multicolumn{2}{c}{ Scaphognathite oscillations/min (Mean \pm S.E) } \\
\cline { 2 - 3 } & Control & Exposed \\
\hline $\mathbf{2 4 h}$ & $247.7 \pm 2.85$ & $253.8 \pm 4.59^{\mathrm{NS}}$ \\
$\mathbf{4 8 h}$ & $248.7 \pm 3.33$ & $227 \pm 4.34^{*}$ \\
$\mathbf{7 2 h}$ & $245.6 \pm 3.26$ & $210 \pm 1.97^{* * *}$ \\
$\mathbf{9 6 h}$ & $246.1 \pm 4.30$ & $231.1 \pm 2.42^{* *}$ \\
\hline
\end{tabular}

Values are Mean \pm S.E; $\mathrm{N}=10 ; *, * *, * * *$ and NS denotes differences in means to be significant at $\mathrm{P}<0.05, \mathrm{P}<0.01$, $\mathrm{P}<0.001$ and non-significant respectively.

\section{M. lamarrei through out the experiment.}

The initial increase in scaphognathite oscillations was noticed after $24 \mathrm{~h}$ exposure followed by continuous decreasing trend observed up to $72 \mathrm{~h}$ exposure than controls. Scaphognathite oscillations again shoot up after $72 \mathrm{~h}$ exposure but remained below than control after $96 \mathrm{~h}$ exposure of copper sulphate.

Initial increase of scaphognathite oscillations may be due to avoidance reaction followed by hypoxia due to metal induced irritation and coagulation of mucous on gill surface (Burba, 1999). It is well known that metals precipitate mucous which forms thick coat on gill surface causing asphyxiation on one hand and prevents further entry of metals in gills on other hands (Plonka and Neff, 1969). The decrease in scaphognathite oscillations in later stage of experiment may be due to altered carbohydrate metabolism (Radhakrishnaiah and Bussapa, 1986) or due to alterations in muscle fibers operating scaphognathite (Schultz and Kennedy, 1977). The decrease in scaphognathite oscillations may also be result of some neurological impairment. Inhibition of Acetyl cholinesterase activity, an enzyme responsible for synaptic transmission, is well reported in Crayfish after cadmium and lead exposure (Devi and Fingerman, 1995), may also be true for altered scaphognathite oscillations in M. lamarrei. Almost similar alterations in ventilatory structures have been reported in fishes (Drastichova $e t$ al., 2004; Sindal et al., 2004; Prashanath et al., 2005 and Svecevièus, 2005) and in other invertebrates (Pane et al., 2003 ; Sen et al., 2008 and Tiwari, 2009) after exposure of various metal compounds.

Changes in oxygen consumption rate are a good index to measure altered metabolic activity in organisms exposed to various toxicants in surrounding medium. Continuous decrease in oxygen consumption, as observed in present study has also been reported in various crustaceans (Bubel, 1976; Chinnaya, 1971; Ghate and Mulherker, 1979; Jadhav and Ambrose, 2007; Papathanasiou and King, 1983; Reddy and Venugopal, 1993; Ketpadung and Tangkrock, 2006; Siddiqui and Siddiqui, 2007 and Sen $e t$ al., 2008) and in other invertebrates (Kumarasamy and 
Table 2. Effect of Copper sulphate on oxygen consumption in Macrobrachium lamarrei.

\begin{tabular}{ccc}
\hline $\begin{array}{c}\text { Duration } \\
\text { of } \\
\text { exposure }\end{array}$ & \multicolumn{2}{c}{ Rate of oxygen consumption $(\mathbf{m g} / \mathbf{l}) / \mathbf{g m}$ body weight/h } \\
\cline { 2 - 3 } $\mathbf{2 4 h}$ & $0.4384 \pm 0.0026$ & Exposed \\
$\mathbf{4 8 h}$ & $0.4225 \pm 0.0081$ & $0.4152 \pm 0.0081^{\mathrm{NS}}$ \\
$\mathbf{7 2 h}$ & $0.4201 \pm 0.0046$ & $0.3677 \pm 0.0012^{*}$ \\
$\mathbf{9 6 h}$ & $0.4090 \pm 0.0038$ & $0.3189 \pm 0.0089^{* *}$ \\
\hline
\end{tabular}

Values are Mean \pm S.E; $\mathrm{N}=10 ; *, * *, * * *$ and NS denotes differences in means to be significant at $\mathrm{P}<0.05, \mathrm{P}<0.01, \mathrm{P}<0.001$ and non-significant respectively.

Karthikeyan, 1999). Similar effects have also been reported in fishes (Hiltibran, 1971; Singh and Singh, 1979; RamanRao and Ramamurthi, 1987; Gill et al., 1988). Reduced oxygen consumption may be due to precipitated mucous coating on gill surface resulting in asphyxiation. The physiological, histological and ultra structural studies have shown that metal ion interferes in respiration by disrupting the structure of gill cells as result of cytotoxic effect (Jones, 1975; Gill et al., 1988; Li-Na, et al., 2007 and Yang et al., 2007). Mitochondrial damage and reduction in ability to synthesize the ATP in gills as reported in Palaemon serratus (Papathanasiou and King, 1983) after exposure of heavy metals may also be a reason for reduced oxygen consumption in M. lamarrei.

It is evident from present findings that metallic pollutants, particularly copper exert adverse effects on scaphognathite oscillations and oxygen consumption of freshwater prawn, M. lamarrei. Scaphognathite oscillations and oxygen consumption rate can be used as monitoring tools to asses worsening status of aquatic bodies in reference to metallic pollution, which is of global concern now days.

\section{ACKNOWLEDGEMENTS}

Authors are thankful to Shri Brijendra Singh, Head, department of Zoology, BSNV PG College, Lucknow, for providing necessary laboratory facilities and Dr.G .C. Mishra, Principal, BSNV PG College, Lucknow, for consistent encouragement throughout the work.

\section{REFERENCES}

APHA (1998). Standard methods for the examination of water and waste water 20thEdition. APHA, AWWA and WPCF, Washington

Bubel, A. (1976). Histopathological and electron microscopical observations on the effects of different salinities and heavy metal ions on the gills of Jerca nordmanni (Rathke) (Crustacea, Isopoda). Cell Tiss. Res., 167: 65-95.

Burba, A. (1999). The effect of copper on behavioural reactions of noble crayfish, Astacus astacus L. Acta. Zoologica. Lituanica Hydrobiologica, 9(2) : 30-36.

Chen, J.C. and Lin, C.H. (2001). Toxicity of copper sulphate for survival, growth, moulting and feeding of juveniles of tiger shrimp, Penaeus monodon. Aquaculture, 192 : 55-65.
Chinnayya, B. (1971). Effect of heavy metals on the Oxygen consumption by the Shrimp Cardina rajadhari Bonvier. Indian J. Exp. Biol., 9: 277-278.

Chopra, A.K., Pathak, C. and Prasad, G. (2009). Scenario of heavy metal contamination in agricultural soil and its management. J. Appl. \& Nat. Sci., 1(1): 99-108.

Devi, M. and M. Fingerman(1995), Inhibition of acetylcholinesterase activity in the central nervous system of the red swamp cray fish Procambarus clarkii, by mercury, cadmium and lead. Bull. Environ. Cotam. Toxicol., 55: 746750.

Drastichova, J, Z. Svobodova, V. Luskova and J. Machova (2004): Effect Cadmium on haematological indices of common carp (Cyprinus carpio). Bull. Environ. Contam. Toxicol., 72(4): 725-735.

Ghate, H.V. and L. Mulherker (1979). Histological changes in the gills of two freshwater prawn species exposed to copper sulphate. Indian J. Exp. Biol., 17: 838-840.

Gill, T.S., J.C. Pant and H. Tiwari (1988). Branchial pathogenesis in a fresh water fish Puntius conchonius Ham., chronically exposed to sub-lethal concentration of cadmium. Ecotoxicol. Environ. Saf., 12 : 267-282.

Hiltibran, R.C. (1971). Effect of Cd, Zn on Oxygen and Phosphate metabolism of blue gill live mitochondria. Jour. Wat. Contr. Fed., 43: 818-823.

Jadhav, S.S. and N.E. Ambrose (2007). Effect of Zine Sulphate on the Oxygen consumption of freshwater crab. Barytelphusa guerini. Aquacult., 8(1): 85-85.

Jones, M. B. (1975). Synergistic effects or salinity temperature on the toxicity of mercury to marine and brackish water isopods (Crustacea). Estuarine Coastal Mar. Sci., 1: 425431.

Ketpadung, R. and Tangkrock, O.N. (2006). Changes in oxygen consumption and heart rate of the blue swimming crab, Protunus pelagicus ( Linnaeus 1766) following sublethal concentration of copper. J.Environ. Biol., 27(1):7-12.

Kumarasamy, P. and A. Karthikeyan (1999). Effect of cadmium on oxygen consumption and filteration rate at different salinities in an estuarine clam Meretrix costa (Chemnitz). J. Environ. Biol., 20 (2): 99-102.

Li-Na, Zhao Y. and Yang J. (2007). Impact of water born copper on the structure of gills and hepatopancreas and its impact on the contents of metallothionein in juvenile gaint freshwater prawn, Macrobrachium rosenbergii (Crustacea-Decapoda). Arch. Environ. Contam. Toxicol., 52 : 73-79.

Liu, F.Y., Liang D.H., Sun F., Li, H.F. and Lan, X. (1990). Effects of dietary copper on prawn, Penaeus orientalis. 
Oceanol. Limnol. Sin., $21: 404-410$.

Lodhi, H.S. (2009) : Effect of copper sulphate on the kidney or green gland of fresh water prawns (Crustacea-Decapoda). Poll. Res., 28 (2) : 187-192.

Lodhi, H.S. M.A. Khan, R.S. Verma and Sharma,U.D. (2006). Acute toxicity of copper to fresh water prawns. J. Environ. Biol., 27(3) : 585-588.

Mandez, L. , Racotta I.S., Acosta B., and Rodriguez-Jaramilloc (2001). Mineral concentration in tissue during ovarian development of white shrimp, Penaeus vannamei (Decapoda - Penaeidae). Mar. Biol., 138 : 687-692.

Pane, E.F., C. Smith, J.C. McGeer and C.M. Wood (2003). Mechanisms of acute and chronic waterborne nickel toxicity in the freshwater Cladoceran, Daphnia magna. Environ. Sci. Technol., 1:37(19): 4382-4389.

Papathanasiou, E. and P.E. King (1983). Ultrastructural studies on the gills of Palaemon serratus (Pennant), in relation to cadmium accumulation. Aquatic Toxicol., 3: 273-284.

Plonka, A.C. and W.H. Neff (1969). Mucopolysaccharide histochemistry of gill epithelial secretions in brook trout exposed to acid pH. Proc. Pa. Acad. Sci., 43: 53-55.

Prashanath, M.S., M. David and S.G. Mathed (2005). Behavionral Changes in freshwater fish, Cirrhinus mrigala (Hamilton) exposed to cypermethrim. J. Environ. Biol., 26(1): 141-144.

Radhakrishnaiah, K. and B. Bussapa (1986). Effect of Cadmium on the carbohydrate metabolism of the freshwater field crab, Oziotelphusa Sensex sensex (Fabricas). J. Environ. Biol., 7(1): 17-21.

Raman Rao and Ramamurthi (1987). Effect of sublethal concentration of cadmium on oxidative metabolism in the freshwater teleost, Tilapia mossambica. Indian J. Comp. Anim. Physiol., 5(2): 71-80.

Reddy, S.L.N. and N.B.R.K. Venugopal (1993). Effect of Cadmium on Acetyl cholinesterase activity and oxygen consumption in a freshwater field crab, Barytelphusa guerini. J. Environ. Biol., 14(3): 230-210.

Sanders, M.J. (1997). A field evaluation of the freshwater river crab, Potamonantes warreni, as a bio accumulation indicator of metal pollution. Thesis, Rand Afrikaans University, South Africa.

Schultz, T.W. and J.R. Kennedy (1977). Analysis of integument and muscle attachment in D. pulex (Cladocera-Crustacea). $J$.
Submicronic. Cytol., 9: 37-51.

Sen, P., Tiwari, K.J., Shukla S., Shukla R. and Sharma U.D. (2008). Effect of Cadmium on ventilation and oxygen consumption of fresh water prawn, Macrobrachium dayanum (Crustacea -Decapoda ). Aquacult., 9(1):95-100.

Sharma, U.D. and S. Shukla (2006). Acute toxicity of heavy metals and detergents to freshwater prawn, Macrobrachium lamarrei (Crustacea-Decapoda). Him . J. Environ. Zool., 20(1): 1-6.

Siddiqui, A.A. and Siddiqui, A.T.M. (2007). Effect of copper sulphate on oxygen consumption and haemolymph sugar level in the fresh water male crab, Barytelphusa gureini. Journal of Indian Society of Toxicology, 3(1) : 15-17.

Sindal, S., A. Tomar, S. Srivastava and A.N. Shukla (2004). Behavioural responses of fish Heteropneustes fossilis exposed to Mercury containing aquatic weeds. Biol. Mem., 30(1): 43-47.

Singh, S.R. and B.R. Singh (1979). Changes in Oxygen consumption of Siluroid fish, Mystus vittatus to different concentration some heavy metal salts. Indian J. Exp. Biol., 1: 271-276.

Sorensen, E.M. (1991). Cadmium In : Metal poisoning in fish. CRC Press, Boca Raton, Florida, PP 175-234.

Svecevièus, G. (2005). Behavioural responses of rainbow trout Onchorhynchus mykiss to sublethal toxicity of a model mixture of heavy metals. Bull. Environ. Contam. Toxicol., 74: 845-852.

Tasi, C.F. (1979). Survival, overturning and lethal exposure time for pearl dace, Semoluis margaritus exposed to Copper solution. Com. Biochem. Physiol., 64: 1-6.

Tiwari, K.J. (2009). Lead induced alterations in Scaphognathite oscillations of fresh water prawn, Macrobrachium dayanum (Crustacea - Decapoda). Environment \& Ecology, 27(1A): 330-333.

Varghese, G., Naik, P. S. and M. Katdare (1992). Respiratory responses and blood sugar level of the crab, Barytelphusa cunicularis (Westwood) exposed to mercury, copper and zinc. Indian Journal of Experimental Biology, 30: 308-312.

Yang, Z.B., Zhao, Y.L.,Li-Na and Yang J. (2007). Effect of water born copper on the microstructures of gill and hepatopancreas of Eriocheir sinensis and its induction of metallothionein synthesis. Arch. Environ. Contam. Toxicol., $52: 222-228$. 